\title{
EKSISTENSI SASTRA LISAN MAMACA \\ DI KABUPATEN PAMEKASAN, MADURA
}

\author{
AM Hermien Kusmayati dan Suminto A Sayuti \\ FSP ISI Yogyakarta dan FBS Universitas Negeri Yogyakarta \\ email: suminto1956@yahoo.co.id
}

\begin{abstract}
Abstrak
Penelitian ini bertujuan mendeskripsikan eksistensi dan fungsi sastra lisan mamaca di Kabupaten Pamekasan, Madura. Sumber data adalah komunitas sastra lisan Mamaca "Rukun Sampurna" di Desa Jalmak, Pamekasan, Madura. Pengumpulan data dilakukan dengan observasi dan wawancara. Data dianalisis berdasarkan pendekatan emik dan etik. Kedua pendekatan digunakan bersama-sama agar objektivitas hasil penelitian dapat dicapai. Hasil penelitian sebagai berikut. Pertama, sastra lisan mamaca dikembangkan oleh komunitas "Rukun Sampurna" dengan pentas secara rutin dan melayani permintaan atau undangan masyarakat untuk acara-acara tertentu. Kedua, sastra lisan mamaca berfungsi mendorong masyarakat menuju tataran yang lebih baik melalui pesan-pesan yang disampaikan. Penonton akan memperoleh inspirasi terkait dengan semangat hidup, optimisme, pencerahan, dan kebahagiaan.
\end{abstract}

Kata kunci: sastra lisan, seni pertunjukkan, fungsi sosial

\section{THE EXISTENCE OF THE MAMACA ORAL LITERATURE IN PAMEKASAN REGENCY, MADURA}

\begin{abstract}
This study aims to describe the existence and functions of the mamaca oral literature in Pamekasan Regency, Madura. The data source was the "Rukun Sampurna" mamaca oral literature community in Jalmak Village, Pamekasan, Madura. The data were collected through observations and interviews. They were analyzed by means of the emic and etic approaches. These two approaches were simultaneously employed to attain the objectivity of research findings. The findings are as follows. First, the mamaca oral community is developed by the "Rukun Sampurna" community through regular performances and fulfillment of the community's requests or invitations for special events. Second, the mamaca oral community stimulates the community to move to a better condition through the delivered messages. The audience will get inspiration for life spirit, optimism, enlightenment, and happiness.
\end{abstract}

Keywords: oral literature, performance art, social function

\section{PENDAHULUAN}

Seni memiliki peran dan fungsi integral bagi masyarakat. Seni, tercakup ke dalam wilayahnya antara lain sastra lisan, dipandang mampu menawarkan berbagai peran ketika ditempatkan di dalam kehidupan bermasyarakat. Seni sangat diperlukan oleh masyarakat yang majemuk dan kompleks, termasuk masyarakat Indonesia.

Dalam perjalanannya, wujud, pelaku, dan penonton beberapa seni tradisi tampak sedikit demi sedikit mulai menyurut dan bahkan menghilang. Di samping itu, 
mayoritas pelakunya sudah berusia relatif tua, sedangkan kalangan muda tidak banyak lagi yang bersedia menjalankannya. Bersama dengan itu, kesetiaan penonton juga meluntur. Akibatnya, proses regenerasinya tidak dapat berjalan dengan mulus, bahkan dapat dikatakan mengkhawatirkan.

Meskipun secara umum seni tradisional mengalami kemunduran, masih ada fakta menarik berkaitan dengan kehidupan seni tradisi di wilayah-wilayah budaya tertentu. Berlawanan dengan fenomena penyusutan wujud, pelaku, maupun penonton, masih dijumpai pendukung seni tradisi yang tampak tegar dan mampu bergerak lebih leluasa, seperti halnya seni tradisi lisan Mamaca yang ada di Kabupaten Pamekasan Madura. Seni tradisi menjadi sarana hiburan, penopang ekonomi, dan bermuatan norma serta nilai pendidikan. Seni tradisi mengalami perkembangan wujud sejalan dengan perkembangan wilayah penyajiannya. Demikian pula dengan pelaku dan penontonnya. Dengan dilatarbelakangi bermacam-macam kepentingan, seni tradisi tetap memperlihatkan denyut kehidupan bersama dengan kebutuhan kehidupan masyarakat selayaknya (Kusmayati, 2000).

Dalam perkembangannya, seni tradisi berdampingan dengan perkembangan media masa yang sangat terbuka. Tidak dapat disangkal bahwa media masa sebagai bagian dari alat untuk berkomunikasi mempunyai pengaruh yang kuat terhadap perkembangan kesenian (Kuntowijoyo, 2006: 12-19). Media komunikasi yang tersedia seperti majalah dan buku buku, radio, dan televisi menghantarkan bermacam macam informasi kepada masyarakat. Bermacam-macam informasi termasuk di antaranya berbagai jenis dan bentuk hiburan yang diketengahkan di dalamnya memberikan sumbangan alternatif seni tradisi yang dapat dinikmati.
Era kesejagadan (globalisasi) yang menipiskan atau bahkan menepis sekat komunikasi berdampingan dengan faktorfaktor lain turut memperkuat perubahan tersebut. Akan tetapi, dalam kaitannya dengan upaya preservasi budaya berikut nilai-nilai tradisi yang bersifat strategis, media komunikasi yang tersedia belum secara keseluruhan memberikan kontribusinya yang bermakna. Bahkan, terdapat kesan media komunikasi justru mengetengahkan sajian yang berdampak terhadap penggerusan seni tradisi tersebut.

Pada sisi yang lain, proses pelaksanaan pendidikan di sekolah yang diharapkan mampu menjadi sarana penerusan nilai-nilai budaya, termasuk seni tradisi semakin jauh dari yang diidealkan. Seharusnya, pendidikan merupakan proses pembudayaan. Dalam kaitan ini pembelajaran seni, termasuk sastra (tradisi) lisan mencakup tiga wilayah utama, yaitu wilayah knowing, doing, dan being (Drake, 2007:12).

Realitas yang adamenunjukkan bahwa proses pembudayaan itu belum dapat dilaksanakan secara maksimal karena berbagai kendala. Para pendidik di sekolah formal maupun non-formal belum banyak yang berbekal, menguasai, atau terampil untuk mengajarkan seni pertunjukan, termasuk seni tradisi lisan kepada peserta didik. Di samping itu, ada fakta lain bahwa tidak semua kurikulum menyediakannya. Para orang tua sering turut berperan mengenalkan seni pertunjukan yang digeluti kepada anak-anak mereka, namun demikian, tidak selamanya berhasil. Tidak semua anak atau anggota keluarga tertarik untuk melanjutkannya. Kadang-kadang anak-anak bersedia berpartisipasi sebatas turut hadir menyaksikan atau menikmatinya sebagai hiburan. Di sisi lain, sebagian di antara mereka menolak apabila diajak menonton apalagi melakukan atau meneruskannya sebagai bagian dalam kehidupan. 
Selama ini pemahaman masyarakat terhadap pendidikan seni terbatas pada pendidikan "tentang" seni. Padahal, implementasi pendidikan "melalui" dan "dengan" seni juga merupakan sebuah konstruk yang perlu terus-menerus diupayakan agar pendidikan benar-benar mewujudkan diri sebagai proses pembudayaan. Dengan cara demikian, masyarakat yang mampu menghargai berbagai ragam seni, termasuk seni tradisi lisan, sekaligus juga berarti mampu menghayati nilai yang ada dalam seni bersangkutan.

Kehidupan seni pertunjukan tradisi lisan yang sehat pada hakikatnya ditandai oleh hubungan yang saling memerlukan antara seniman, pengamat seni/pendidikan, dan masyarakat penikmat. Akan tetapi, dalam kenyataannya selain tidak mampu mempertahankan pelaku dan penikmatnya, seni tradisi kurang memiliki peluang untuk memberikan peningkatan yang bernilai ekonomi. Akibatnya, perkembangan yang diharapkan menjadi terbatas, baik dalam hal perkembangan wujud dan wilayah persebaran.

Berdasarkan uraian di atas, menarik untuk dikaji keberlangsungan kehidupan seni tradisi yang ada di masyarakat, khususnya tradisi lisan yang hidup di masyarakat Madura. Masih dalam bingkai tradisinya, seni sastra lisan di Madura tumbuh dan mekar di antara tatanan kehidupan yang dipenuhi oleh berbagai tuntutan (Mulyono, 1985). Seni tradisi (sastra) lisan menampakkan diri di selasela ragam kebutuhan.

\section{METODE}

Sehubungan dengan kehidupan seni tradisi lisan di Madura, khususnya di wilayah Daerah Tingkat II Kabupaten Pamekasan, penelitian ini difokuskan pada seni tradisi lisan yang dipilih, yakni tradisi lisan Mamaca. Lebih lanjut kegiatan penelitian dimaksudkan pula untuk mengikuti jejak persebaran tradisi lisan tersebut ke daerah atau wilayah di Madura lainnya. Hasil pemetaan yang dilakukan bisa dipertimbangkan sebagai stockhouse bagi upaya pengembangannya, baik dalam perspektif edukatif, kultural, maupun ekonomi kreatif.

Pengumpulan data melalui survei dan observasi. Kegiatan survei dan observasi dilaksanakan untuk mengetahui aktivitas tradisi lisan Mamaca di tengah-tengah masyarakat. Di samping itu, pengumpulan data juga dilakukan teknik wawancara dengan narasumber yang dipilih berdasarkan kapasitas dan kepakaran masing-masing. Pemilihan narasumber dimaksudkan untuk lebih mendapatkan kelengkapan dan kejelasan data.

Penelitian ini bersifat analitis-kualitatif-implementatif. Kegiatan analisis data dilaksanakan berdasarkan pendekatan emik maupun etik. Kedua pendekatan ini diperlukan dan digunakan bersama-sama agar objektivitas hasilnya dapat dicapai. Analisis data diperkaya dengan informasi aspek sosiologis kehidupan masyarakat Madura dari berbagai sumber pustaka yang relevan.

\section{HASIL DAN PEMBAHASAN}

Tradisi lisan Mamaca yang dikenal di Madura tampak memiliki pertalian dengan tradisi macapat yang hidup dan berkembang di Pulau Jawa (utamanya Jawa Tengah) sejak masa Mataram (Tjiptoatmodjo, 1983: 18-21). Keberadaan tradisi lisan Mamaca erat kaitannya dengan kehidupan sosial masyarakat pendukungnya. Tradisi ini terlahir sebagai salah satu sarana pemenuhan kebutuhan masyarakat di tempat tradisi itu tumbuh dan berkembang. Masyarakat Madura dikenal dengan masyarakat yang memiliki tradisi keagamaan (Islam) yang sangat kuat (Bouvier, 1995:119). Kehadiran tradisi lisan Mamaca menjadi penegas karakteristik masyarakat Madura karena sajian Mamaca bersumber dari teks-teks bersifat didaktis dan moralitas yang dipengaruhi budaya Islam. 


\section{Eksistensi Sastra LisanMamaca di Kabu- paten Pamekasan}

Di wilayah Kabupaten Pamekasan berkembang seni pertunjukan yang disebut Mamaca. Dalam aktivitas pertunjukannya, seni Mamaca ini dilakukan oleh kaum laki-laki. Secara konseptual Mamaca (bahasa Madura) berarti membaca suatu kisah yang bersumber dari naskah tertentu. Naskah ini dinamakan juga Kitab atau lebih lazim terdengar sebagai Layang. Kegiatan membaca dilakukan dengan cara melakukan bergantian seorang demi seorang dan kadang-kadang bersamasama. Seseorang yang bertindak sebagai pelantun Mamaca dinamakan pamaos, berarti pembaca. Irama lagu pembacaan mengikuti bermacam-macam pola tetembangan berlaras slendro yang membingkai kalimat-kalimat yang dibaca dari Kitab atau Layang tersebut. Pola-pola tetembangan ini identik dengan tradisi macapat sebagaimana di Pulau Jawa (Kusumayati, 2000).

Naskah yang disebut Kitab atau Layang sebagai sumber bacaan bertuliskan huruf Arab pégon dan berbahasa Jawa Baru. Kitab atau Layang berisi bermacam-macam cerita yang mendapat pengaruh budaya Islam. Oleh karena itu, salah seorang di antara pelaku Mamaca berperan sebagai penerjemah atau dinamakan panegghesdengan menggunakan bahasa Madura. Panegghes menyampaikan pengertian kalimat-kalimat yang dibaca oleh pamaos dalam bahasa Jawa Baru ke dalam Bahasa Madura. Penerjemahan dalam bahasa Madura disampaikan berselang-seling dengan pamaos ketika kalimat demi kalimat atau bait demi bait selesai dilagukan. Penyajian Mamaca kadang-kadang juga diiringi dengan suara tiupan seruling atau tabuhan gambang.

Beberapa naskah Mamaca yang populer antara lain Layang Nurbuwat, Layang Yusuf, dan Layang Pandhâbâ. Ketiga Layang ini sering menghantarkan berbagai perhelatan yang dimaksudkan untuk me- menuhi bermacam-macam kepentingan. Pimpinan kelompok Mamaca mengetahui dan menyesuaikan bacaan yang akan disajikan dengan perhelatan yang dilaksanakan. Tidak hanya pimpinan, tetapi anggota kelompok dan juga sebagian besar masyarakat mengetahui cerita yang akan ditampilkan sehubungan dengan peristiwa yang sedang dilangsungkan. Para tamu menantikan kumandang tembang pamaos yang disusul oleh suara panegghes dengan sisipan humor-humornya (Kusmayati, 1999).

Layang Nurbuwat yang memuat kisah para Nabi dibacakan ketika memperingati Isra' dan Mi'raj Nabi Muhammad SAW. Sebagian dari naskah tersebut, yaitu yang mengemukakan kisah dan kebesaran Nabi Muhammad SAW dilagukan sepanjang malam. Pembacaannya dimulai sekitar pukul 20.00 setelah sembahyang isya sampai sekitar pukul 24.00. Biasanya, peringatan peristiwa keagamaan ini diselenggarakan oleh suatu panitia yang mengundang kelompok Mamaca untuk turut memeriahkannya.

Suatu keluarga dapat pula meminta atau mengundang kelompok Mamaca untuk menjadi bagian sarana dalam upacara tujuh bulan kehamilan anak pertama. Sehubungan dengan upacara yang diselenggarakan, maka kelompok Mamaca akan menyajikan Layang Yusuf sebagai sumber bacaannya. Layang yang dilagukan disesuaikan dengan peristiwa yang dilaksanakan pada waktu itu. Layang Yusuf dilagukan pada waktu itu dengan harapan bahwa ketampanan dan kebaikan Nabi Yusuf dapat memberikan berkah kepada keluarga yang sedang melaksanakan upacara, terutama agar kebaikan dan ketampanannya dapat menurun kepada calon bayi yang masih dalam kandungan

Apabila upacara ini disatukan dengan rokat Pandhâbâ untuk calon ibu yang sedang hamil tujuh bulan dan sedang diupacarakan itu, maka dapat pula dilagukan Layang Pandhâbâ. Upacara atau ritual 
rokat dalam tradisi Jawa dikenal dengan istilah ruwatan. Baik Layang Pandhâbâ maupun Layang Yusuf mulai dilagukan sekitar pukul 20.00. Pembacaan Layang harus sudah selesai sebelum pukul 24.00 karena upacara inti rokat Pandhâbâ dilaksanakan pada tengah malam sekitar pukul 24.00. Layang Pandhâbâ disajikan pula dalam rangkaian peristiwa pernikahan yang dilaksanakan dengan rokat Pandhâbâ.

Upacara Rokat dilaksanakan bagiorangorang yang mendapat sebutan pandhâbâ. Dalam pandangan masyarakat Madura, yang termasuk dalam kategori pandhaba adalah anak tunggal laki-laki atau perempuan, dua bersaudara laki-laki dan perempuan, lima bersaudara laki-laki, seorang laki-laki di antara beberapa saudara perempuan, dan seorang perempuan di antara beberapa saudara laki-laki. Anak tunggal laki-laki disebut pandhâbâ macan. Anak tunggal perempuan disebut pandhâbâ rato. Dua bersaudara laki-laki dan perempuan dinamakan pandhâbâ pangantan atau pandhâbâ ta antèng. Dua bersaudara laki-laki juga disebut pandhâbâ ta antèng. Lima bersaudara laki-laki disebut pandhâbâ lèma'. Mereka yang membawa ciri tertentu ini secara tradisi dipercaya akan terbebas dari marabahaya apabila diupacarakan rokat pandhâbâ. Pelaksanaannya biasanya dirangkai dengan upacara pernikahan atau upacara tujuh bulan kehamilan pertama untuk ruwatan anak perempuan.

Upacara ruwatan ini sangat terkenal di kalangan masyarakat Madura, terutama di wilayah Sumenep dan Pamekasan. Rokat Pandhâbâ dilakukan agar manusia dengan ciri-ciri tersebut di atas terhindar sebagai mangsa Bathara Kala. Cerita tradisi seperti di Jawa dan Bali yang tersinggahi oleh budaya Hindu mengisahkan bahwa Bathara Kala yang bersosok raksasa adalah putera Bathara Guru dengan Dewi Uma. Ia lahir karena karma yang salah. Orang-orang berciri pandhâbâ adalah santapan Bathara Kala yang dijanjikan oleh Bathara Guru.Cerita tentang Bathara
Kala inilah yang sering ditampilkan oleh kelompok Mamaca ketika suatu keluarga menyelenggarakan pernikahan dan tujuh bulan kehamilan anak pertama.

\section{Kehidupan Kelompok Mamaca "Rukun Sampurna"}

Perkembangan tradisi lisan Mamaca di Kabupaten Pamekasan dipelopori oleh Haji Sastra, seorang Pengawas Sekolah Taman Kanak-Kanak dan Sekolah Dasar Kecamatan Tlanakan Kabupaten Pamekasan. Dia menekuni dan mengembangkan seni tradisi lisan ini dari warisan mendiang ayahnya, yaitu Bapak Kamsito. Dalam mengembangkan dan melestarikan tradisi lisan Mamaca, Haji Sastro dibantu Bapak Suparno. Secara khusus, Bapak Suparno juga melanjutkan tradisi ini dari almarhum ayahnya, yaitu Bapak Dulamad. Bapak Kamsito dan Bapak Dulamad adalah dua orang yang mengawali kehadiran Mamaca di Desa Jalmak Kecamatan Pamekasan pada tahun 1970-an. Mereka berdua sejak tahun 1970-an bersama dengan beberapa orang warga mewadahi kegiatan seni tradisi lisan tersebut ke dalam perkumpulan yang dinamakan 'Rukun Sampurna'. Dalam pengelolaan kelompok 'Rukun Sampurna', Bapak Kamsito sebagai pimpinan, sedangkan Bapak Dulamad duduk sebagai panegghes. Kedudukan keduanya sebagai pimpinan dan panegghes diturunkan kepada anak-anak lelaki mereka, yaitu Haji Sastro dan Bapak Suparno.

Sejak Bapak Kamsito dan Bapak Dulamad masih aktif di "Rukun Sampurna", Bapak Sastra maupun Bapak Suparno sudah dilibatkan ke dalam kelompok ini. Upaya kedua orang tua tersebut tidak siasia karena kedua anak mereka kemudian melanjutkan dan menekuni seni tradisi lisan Mamacayang sudah dilakukan dan dibina sebelumnya. Sejak tahun 1983 , setahun setelah menyelesaikan pendidikan Diploma 1 di Sekolah Tinggi Kesenian Wilwatikta Surabaya di bidang Karawitan, Bapak Sastra menggantikan ayahnya. Ke- 
tika itu, Bapak Sastra menjabat sebagai Kepala Seksi Kebudayaan Kecamatan Tlanakan Kabupaten Pamekasan.

Bapak Sastra dan Bapak Suparno melanjutkan aktivitas ayah mereka dengan terus mengajak laki-laki dewasa di wila-yah Desa Jalmak Kecamatan Pamekasan untuk bergabung ke dalam 'Rukun Sampurna'. Kelompok ini meneruskan rutinitas para pendahulu, yaitu menyelenggarakan pembacaan naskah-naskah sebagai sebuah bentuk seni pertunjukan Mamaca. Kegiatan dilakukan setiap hari Minggu malam setelah sembahyang isya, antara pukul 20.00-22.00.

Tempat pelaksanaan bergantian dari satu rumah anggota ke rumah anggota yang lain. Kegiatan rutin dimaksudkan juga sebagai kesempatan berlatih melagukan naskah-naskah bagi para anggota, terutama untuk anggota baru yang belum bisa melakukannya. Pertemuan setiap Minggu malam dirangkai pula dengan arisan sebagai upaya untuk lebih mengikat para anggota agar hadir.

Kelompok Mamaca' Rukun Sampurna' selain menyelenggarakan pertemuan secara rutin juga menerima permintaan atau undangan dari warga masyarakat. Keterlibatan anggota yang akan melaksanakan pementasan ditentukan oleh Bapak Sastro sebagai pimpinan dan Bapak Suparno sebagai pelatih. Anggota yang belum mampu melakukan Mamaca dengan lancar dapat memahami apabila belum dilibatkan dalam suatu pementasan. Para anggota diharapkan terus terlibat dalam kegiatan Mamaca yang diadakan secara rutin sebagai sarana memperlancar dan menguasai kegiatan Mamaca.

Besaran biaya pementasan diserahkan pada kemampuan pengundang. Akan tetapi, mereka minta disediakan biaya atau kendaraan untuk membawa anggota ke tempat tujuan berangkat dan pulang, apabila undangan berasal dari luar Pamekasan.
Permintaan untuk menyajikan $M a$ maca tidak sebatas di wilayah Kabupaten Pamekasan, tetapi melebar sampai Kabupaten Sampang yang terletak di sisi barat Pamekasan dan Sumenep yang mengapit di sisi timur. Pengundang meminta pergelaran Mamaca untuk menyertai bermacammacam kepentingan. Beberapa undangan yang pernah diterima antara lain untuk memeriahkan pernikahan, khitan, dan merayakan peringatan hari-hari besar keagamaan maupun nasional. Di samping sebagai pemeriah suasana perayaan, seni tradisi lisan ini juga masih ditempatkan sebagai sarana upacara, khususnya upacara rokat Pandhâbâ.

Dalam pementasan, semua pelaku memakai kemeja berlengan panjang, berkain sarung, dan mengenakan kopiah. Mereka duduk bersila dan melingkari beranda atau ruang tamu yang dihampari tikar. Layang tertentu yang akan dibacakan diketakkan di atas bantal. Layang beralaskan bantal ini akan berpindah tempat sesuai dengan tempat duduk pamaos-nya. Suara pamaos, panegghes, dan tiupan seruling atau tabuhan gambang akan terdengar berselang-seling dan kadang-kadang serentak bersama. Jika pelaksanaan $M a-$ maca bersamaan atau untuk kepentingan suatu upacara, benda-benda sarana upacara diletakkan di tengah lingkaran. Pada umumnya, tuan rumah (pengundang) menyediakan sajian makanan kecil, kopi, dan rokok. Kopi dan kelengkapannya dinikmati bersama sebelum dimulai dan pada waktu istirahat.

Dalam kesempatan istirahat, disela-sela menikmati hidangan yang disediakan, kadang-kadang tuan rumah atau tamu minta dilakukan oghem atau semacam ramalan. Ramalan atau oghem berdasarkan Layang yang digunakan atau dibaca dalam kesempatan itu. Pamaos membuka secara acak lembar-lembar Layang dan membacakan beberapa kalimat dari suatu halaman kemudian panegghes memaknakannya. Kegiatan oghem lebih dimaksudkan se- 
bagai penghormatan kepada tuan rumah atau tamu serta sebagai perintang waktu daripada kesungguhan maknanya.

Bapak Sastro yang memiliki kemampuan meniup seruling menempatkan kemampuan tersebut dalam Mamaca selain juga menjadi pamaos sebagaimana keharusan untuk dilakukan oleh semua anggota. Kecintaan dan kepedulian terhadap kesenian mendorongnya untuk meluaskan kegiatan berkesenian kelompok. Ia mengajak anggota "Rukun Sampurna" berlatih gamelan. Seperangkat gamelan terbuat dari besi berlaras slendro dibeli sedikit demi sedikit. Seluruh anggota tidak keberatan menyisihkan uang lelah yang diperoleh pada waktu pementasan untuk membeli gamelan tersebut.

Usahanya tampak tidak sia-sia. Sejak tahun 2004 tumbuh kelompok karawitan yang menamakan diri "Bintang Kemala". Karawitan ini beranggotakan beberapa anggota "Rukun Sampurna" ditambah beberapa anggota baru yang tertarik untuk belajar karawitan. Seperti juga kelompok Mamaca "Rukun Sampurna", karawitan "Bintang Kemala" menerima undangan untuk berpentas. Kegiatannya terbatas di wilayah Kabupaten Pamekasan. Kepentingan pementasannya untuk pemeriah suasana.

Tanggung jawab sebagai pelanjut budaya dan pengawas pendidikan dipahami benar oleh Bapak Sastro. Upayanya tidak berhenti sampai dengan berkegiatan seni di dalam "Rukun Sampurna" dan "Bintang Kemala". Berbagai upaya juga dilakukan untuk keberlanjutan tradisi warisan nenek moyang yang dikuasainya. Diselipkannya bait-bait tembang sederhana dalam pelajaran bahasa Madura yang ditulis sebagai buku ajar untuk Sekolah Dasar (1996) dan Sekolah Lanjutan Pertama (2004). Para guru sekolah diminta untuk mengajarkan tembang-tembang sederhana berbahasa Madura kepada para murid, setidaknya di Kecamatan Tlanakan, wilayahnya bekerja.
Selanjutnya, Pak Sastra juga melakukan kegiatan pengumpulan ragam kata bahasa Madura. Hasil kerja keras mengumpulkan ragam kata itu kemudian menjadi Kamus Bahasa Madura - Indonesia (2007). Bapak Sastro juga membuat dan mempopulerkan kembali ikat kepala tradisi Pamekasan. Keluarga dan kerabat diminta untuk mengenakan pakaian tradisi ini dalam kesempatan yang sesuai.

\section{Dimensi Sosial Tradisi Lisan Mamaca}

Secara sosiologis, seni pertunjukan bisa saja memerankan fungsinya yang bersifat komunikatif. Artinya, melalui pergelaran seni pertunjukan dapat dipropagandakan berbagai hal sejalan dengan kapabilitas dan kewenangan seni pertunjukan itu sendiri. Berbagai macam nilai bisa disosialisasikan melalui gelar seni pertunjukan. Nilai-nilai yang hampir sepenuhnya bersifat pragmatis-sekuler dan menghibur dapat dikomunikasikan melalui seni perunjukkan, termasuk tradisi lisan seperti Mamaca.

Nilai yang bersifat filosofis-transendental dapat dipetik masyarakat penonton yang menghendaki melalui pergelaran Mamaca. Pergelaran seni ini berangkat dari teks-teks tertentu yang isinya memang bersifat didaktis dan moralistis. Teksteks yang dibawakan pada gelar Mamaca disesuaikan dengan kepentingan yang punya hajat. Dalam penyajiannya, tradisi lisan Mamaca disaksikan penonton/pendengar yang terbatas. Penonton Mamaca biasanya adalah para tetangga dekat yang punya hajat, terutama sanak keluarga sendiri. Mamaca adalah seni pertunjukan yang jauh dari hingar bingar. Mamaca dapat dikatakan sebagai bentuk seni pertunjukan yang "diam". Para penonton/ pendengarnya membangun relasi secara diam-diam dengan makna teks-teks yang dibawakan.

Sepanjang Mamaca digelar, hampir tidak pernah terdengar suara orang tertawa karena merasa "terhibur". Pada 
kesempatan tertentu, sesekali saja terdengar suara riuh tertawa pada saat sang penerjemah menyelipkan humor-humor segar di sela-sela menyampaikan terjemahan tembang yang sedang dibaca. Para penonton/pendengar hampir semuanya tenggelam dalam kesungguhan mengikuti irama Mamaca atau parafrasenya dalam bahasa prosa yang dibawakan oleh sang penerjemah. Mamaca adalah bentuk seni pertunjukan tradisi lisan yang relatif masih tergolong serius.

Penjelasan di atas menunjukkan bahwa tradisi lisan Mamaca juga memfasilitasi masyarakat penonton dengan cara menawarkan dan menginformasikan beragam nilai alternatif: baik-buruk, pantastidak pantas (Kusmayati, 1999). Mamaca akan mendorong masyarakat menuju tataran yang lebih baik melalui pesanpesan yang disampaikan. Penonton akan memperoleh inspirasi terkait dengan semangat hidup, optimisme, pencerahan, dan kebahagiaan.

Tradisi lisan Mamaca, pada hakikatnya juga dapat diperhitungkan sebagai sebuah situs ideologis yang di dalamnya berbagai ideologi bertarung, saling meniadakan, saling melengkapi, dan saling memperkaya hingga akhirnya tercapai keseimbangan dalam harmoni yang dibingkai estetisasi pergelaran. Oleh karena itu, dapat dipahami mengapa sebagai bentuk seni pertunjukan, Mamaca menunjukan sifatnya yang selalu dinamis agar mampu memposisikan dirinya dalam jaringan sosial yang mengepung dan membesarkannya.

Apabila dicermati dengan saksama, terdapat dua kecenderungan utama yang terjadi pada seni pertunjukkan. Hal itu tentunya juga berlaku pada tradisi lisan Mamaca. Pertama, seni pertunjukan berposisi atau bertindak sebagai semacam agen yang melayani citarasa penanggap atau penonton dengan cara mengelaborasi pesanan penanggap atau penonton. Apapun yang menjadi kehendak si pe- nanggap, sepanjang dapat dilaksanakan dan mereka mampu, akan dilayani. Itu pula sebabnya di sela-sela gelar Mamaca (yang notabene merupakan bentuk seni pertunjukan "diam") sering diselingi dengan sisipan "ramalan," disamping humorhumor yang dilontarkan sang penerjemah tatkala menyampaikan parafrase tembang yang sedang dibaca.

Kedua, seni pertunjukan berposisi atau bertindak sebagai semacam agen yang di samping melayani juga berupaya mengakomodasi berbagai kehendak, baik yang berasal dari penanggap, penonton, maupun dari seni pertunjukan itu sendiri. Dalam kaitan ini yang menjadi acuan adalah norma-norma budaya yang telah menjadi konvensi.

Kesadaran terhadap fungsi dan posisi tersebut diwujudkan melalui berbagai upaya yang dapat dilakukan dan terjangkau. Pertama, yakni kegiatan latihan yang diadakan secara rutin. Kelompok-kelompok seni pertunjukan yang ada selalu mengadakan latihan rutin. Latihan itu ditingkatkan frekuensinya apabila menjelang pentas. Di sisi lain, kelompok-kelompok seni tersebut juga selalu berupaya menjaga nilai-nilai hiburan dan ajaran dengan cara menghindari munculnya "kreativitas" yang tidak terkendali (kebablasen).

Kedua, membangun kebanggaan kolektif atau melakukan pencitraan. Kebanggaan kolektif ini tidak hanya sebatas pada kolektivitas kelompok seni tersebut, tetapi juga mencakup kebanggaan masyarakat tempat kelompok seni pertunjukan itu berada. Di samping untuk forum komunikasi, kelompok seni dapat pula diberdayakan untuk membangun ikon kebanggaan kolektif karena merujuk pada wilayah asal kelompok seni yang bersangkutan.

Sebagaimana halnya masyarakat di Dusun Jalmak Pamekasan Madura sebagai pemiliki kolektif tradisi lisan $M a-$ maca. Keberadaan perkumpulan "Rukun Sampurna" sebagai pelestari tradisi lisan 
Mamaca secara langsung maupun tidak langsung berpengaruh pada eksistensi masyarakat setempat. Warga masyarakat memiliki kebangganggaan tersendiri dengan adanya kelompok pelaku dan penjaga tradisi lisan Mamaca.

Upaya-upaya seperti dilukiskan di atas menunjukkan bahwa kelompokkelompok seni yang ada selalu ingin mencapai atau mempertahankan "wibawa" tertentu, baik pada tataran personal maupun kolektif dalam upaya mencapai atau mempertahankan eksistensi dan derajat kesenimanan. Bisa dipahami jika di kalangan mereka berlaku atau terdapat semacam "standar" tertentu untuk mengukur derajat kesenimanan.

\section{SIMPULAN}

Berdasarkan hasil dan pembahasan penelitian yang disajikan di atas dapat disimpulkan tiga hal sebagai berikut. Pertama, meskipun secara umum seni tradisi mengalami kemunduran, masih dijumpai pendukung seni tradisi yang tegar dan mampu bergerak leluasa, se-perti halnya seni tradisi lisan Mamaca di Kabupaten Pamekasan Madura.

Kedua, perkembangan tradisi lisan $M a-$ maca di Kabupaten Pamekasan dipelopori oleh Haji Sastra dan Bapak Suparno yang meneruskan tradisi ini dari orang tua. Upaya pelsetarian tradisi lisan Mamaca dilakukan dengan dua cara, yaitu (1) pentas secara rutin dan (2) melayani permintaan atau undangan dari masyarakat untuk acara-acara tertentu.

Ketiga, sastra lisan Mamaca berfungsi mendorong masyarakat menuju tataran yang lebih baik melalui pesan-pesan yang disampaikan. Penonton akan memperoleh inspirasi terkait dengan semangat hidup, optimisme, pencerahan, dan kebahagiaan. Nilai yang bersifat filosofis-transendental dapat dipetik masyarakat penonton yang menghendaki melalui pergelaran Mamaca. Pergelaran tradisi lisan ini menyajikan pembacaan teks-teks tertentu yang isinya bersifat didaktis dan moralistis. Teksteks yang dibawakan pada gelar Mamaca disesuaikan dengan kepentingan yang punya hajat.

\section{UCAPAN TERIMA KASIH}

Artikel ini disarikan dari laporan penelitian Hibah Kompetitif Penelitian Prioritas Nasional Batch I tahun 2010. Untuk itu, ucapan terima kasih disampaikan DP2M DIKTI yang telah memfasilitasi pendanaan dalam kegiatan penelitian ini. Ucapan terima kasih disampaikan kepada narasumber dan informan, khususnya Bapak Sastra dan Bapak Suparno serta para anggota Kelompok "Rukun Sampurna" yang telah memberikan bantuan selama proses penelitian ini.

\section{DAFTAR PUSTAKA}

Bouvier, Helene. 1994. La Matiere des Emotionns: Les Arts du Temps et du Spectacle Dans la Societe Madouraise (Indonesie). Paris: L'Ecole Francaise D'ExtremeOrient

Drake, S.M. 2007. Creating Standards-Based Integrated Curriculum. Ontario: Brock University.

Kuntowijoyo. 2006. Budaya dan Masyarakat. Yogyakarta: Tiara Wacana.

Kusmayati, A.M. 2000. Arak-arakan: Seni Pertunjukkan dalam Upacara di Madura. Yogyakarta: Tarawang

Kusmayati, A.M. 1999. “Seni Pertunjukan di Pulau Madura: 1980 - 1998". Disertasi. Yogyakarta: Universitas Gadjah Mada.

Mulyono dkk. 1985. Mengenal Sekelumit Kebudayaan Orang Madura di Sumenep. Yogyakarta: Balai Kajian Sejarah dan Nilai Tradisional Depdikbud.

Tjiptoatmodjo, F.A.S. 1983. “Kota-kota Pantai di Sekitar Selat Madura Abad XVII sampai Medio Abad XIX. Disertasi. Yogyakarta: Universitas Gadjah Mada 